
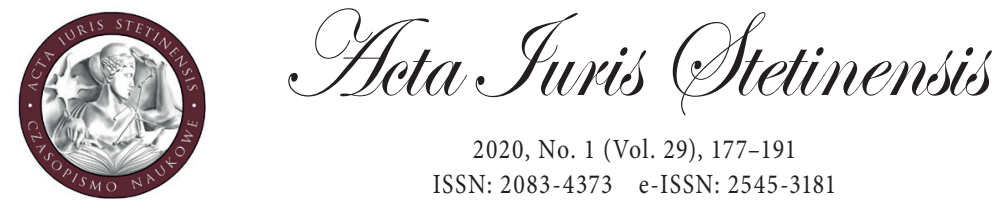

2020, No. 1 (Vol. 29), 177-191

ISSN: 2083-4373 e-ISSN: 2545-3181

DOI: $10.18276 /$ ais.2020.29-12

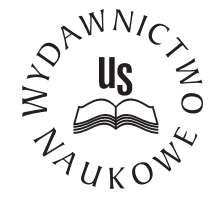

Aneta Tyc

Ph.D.

University of Lodz, Poland

Faculty of Law and Administration

e-mail: atyc@wpia.uni.lodz.pl

OPEN ACCESS

ORCID ID: 0000-0003-0593-2862

\title{
Corporate social responsibility instruments and their impact on labour rights ${ }^{1}$
}

\begin{abstract}
The aim of this article was to assess to what extent self-regulation within the CSR framework contributes to improving workers' rights worldwide. Transnational company agreements, corporate codes of conduct, NGOs' social accountability standards, ISO standards, the Dow Jones Sustainability Index and the Global Reporting Initiative were critically analysed using logical-linguistic, historical and comparative legal methods. The research showed some evidence of a limited impact of CSR instruments on labour rights and proved that CSR tools can be perceived only as additional value to law.
\end{abstract}

Keywords: labour rights, corporate social responsibility, private standard-setting

\section{Introduction}

In the era of global value chains and turbulent debates on trade policies, we have to consider how to ensure decent work for all. Within the powerful machinery of

1 The project was financed by the National Science Centre in Poland pursuant to decision number DEC-2016/21/D/HS5/03849. The project's registration number is: 2016/21/D/HS5/03849. 
world trade, social concerns can be expressed in many ways, e.g. in mega-regional trade agreements, the Generalized System of Preferences or even through the flexible interpretation of WTO exceptions, allowing trade sanctions for reasons related to violations of workers' rights. However, labour standards can also be included in the entire spectrum of private norms. The aim of this article is to assess to what extent self-regulation within the corporate social responsibility (CSR) framework contributes to improving workers' rights worldwide. The study aims at providing an overview of some crucial instruments in the field of CSR: transnational company agreements, corporate codes of conduct, NGOs' social accountability standards, ISO standards, the Dow Jones Sustainability Index and the Global Reporting Initiative.

Before scrutinising this in more detail, one should first define the term CSR, which is understood as "an umbrella term for a variety of theories and practices, all of which recognise the following: (a) that companies have a responsibility for their impact on society and the natural environment, sometimes beyond legal compliance and the liability of individuals; (b) that companies have a responsibility for the behaviour of others with whom they do business (e.g. within supply chains); and (c) that business needs to manage its relationship with the wider society, whether for reasons of commercial viability or to add value to society." ${ }^{2}$

The research method is based on an analysis and criticism of all the abovementioned instruments, as well as relevant literature. Historical, comparative and logical-linguistic legal methods are also used, and the synthesis is an investigative technique for the development of the accumulated literature.

\section{Transnational company agreements}

Transnational Company Agreements (TCAs) can be divided into European Framework Agreements (EFAs) and International/Global Framework Agreements (IFAs/ GFAs). As regards the latter, they are negotiated and signed by a multinational company and at least one Global Union Federation (GUF). ${ }^{3}$ As Schömann points out, unlike IFAs, which are a global instrument aimed mainly at ensuring international labour standards (especially ILO core labour standards) in all of the target

2 Blowfield, M. and Frynas, J.G., Editorial. Setting new agendas: Critical perspectives on corporate social responsibility in the developing world, "International Affairs" 2005, No. 81, p. 503, as quoted in: Lund-Thomsen, P. and Lindgreen, A., Corporate social responsibility in global value chains: where are we now and where are we going?, "Journal of Business Ethics" 2014, No. 123, p. 12. DOI: 10.1007/s10551-013-1796-x (accessed 23.11.2019).

3 Ojeda-Avilés, A., Transnational labour law, Alphen aan den Rijn 2015, p. 237. 
company's locations, EFAs embrace more issues and are regionally limited. The author, however, further adds that this difference is vanishing, as it can be observed that, on the one hand, IFAs are becoming much more detailed, and on the other hand, international aspects appear with increasing frequency in EFAs. ${ }^{4}$

There are considerable advantages of TCAs. As pointed out by Schömann, owing to social dialogue with trade unions, these tools are considered as means of promoting industrial peace. Trade unions and workers are involved in drafting, monitoring and implementing TCAs. Trade unions help solve problems related to the implementation of these agreements and provide an alternative dispute resolution mechanism. From the point of view of trade unions, TCAs contribute to involving MNCs in a private standard-setting process with the aim of increasing the quality of working conditions and strengthening the rights of local unions. On the other hand, from the perspective of MNCs, TCAs - similarly to other private instruments - help build a good reputation and avoid unfavourable public campaigns. ${ }^{5}$

As of November 2019, over 300 TCAs have been signed, including over 100 IFAs. ${ }^{6}$ The first IFA was signed in 1988 between the French food company Danone, which could boast of a reputation for social partnership and a progressive attitude to CSR, ${ }^{7}$ and the International Union of Food and Allied Workers' Association (IUF). ${ }^{8}$ The second was signed with the ACCOR hotel chain in $1995 .{ }^{9}$ Despite their growing popularity, questions still arise, for example, as to their legal value, legal nature, as well as legal impact. There is no legal framework under which TCAs are

4 Schömann, I., Transnational company agreements: towards an internationalisation of industrial relations, in: Schömann, I. et al. (eds.), Transnational collective bargaining at company level. A new component of European industrial relations?, Brussels 2012, pp. 202-203, https://www.etui.org/ Publications2/Books/Transnational-collective-bargaining-at-company-level.-A-new-component-of-European-industrial-relations (accessed 23.11.2019).

5 Ibidem, p. 204. See the cited literature.

6 The list of all identified TCAs can be found at: https://ec.europa.eu/social/main.jsp?catId=978\&langId=en (accessed 23.11.2019).

7 Cotton, E., Employment relations, international framework agreements and global unions, in: Roper, I. et al., (eds.), Critical issues in human resource management: contemporary perspectives, London 2020, p. 145.

8 Barrier, D., National policy regimes: implications for the activism-policy nexus, in: Utting, P. et al., (eds.), Global justice activism and policy reform in Europe: understanding when change happens, New York-London 2012, p. 52.

9 Barreau, J., and Arnal, J., Effects of financialization on restructuring and sustainable development policy: the ACCOR group case, in: Sun, W. et al. (eds.), Finance and sustainability: towards a new paradigm? A post-crisis agenda, Bingley 2011, p. 268. 
created, and thus the legal nature of such a norm as TCAs is conditional upon the powers granted by law to MNCs and trade unions. ${ }^{10}$

\section{Corporate codes of conduct}

Self-regulation through TCAs is only one of the pathways of corporate law development. The other is related to corporate codes of conduct, which are defined as "unilateral recommendations through which the main decision-making bodies of companies set up rules of behaviour for managers and employees (sometimes also for suppliers and subcontractors) that reflect the principles and values of corporate social responsibility" ${ }^{11}$ They have their roots in the 1970s, when the number of reports concerning unethical or illegal activities of MNCs increased and led to discussions within international organisations. ${ }^{12}$ This laid the foundation for, inter alia, the UN Draft Code of Conduct on TNCs, the OECD Guidelines for Multinational Enterprises and the ILO Tripartite Declaration of Principles concerning Multinational Enterprises and Social Policy. Furthermore, many codes of conduct were established to provide a stable framework in which MNEs conduct their business ${ }^{13}$ (the first generation of codes of conduct).

The second wave of codes appeared in the early 1990s and paid much attention to labour conditions. ${ }^{14}$ In 1992, Levi Strauss adopted so-called "Global Sourcing and Operating Guidelines," ${ }^{15}$ which were described as belonging to the second generation of codes. ${ }^{16}$ This was the first supplier code of conduct for the apparel industry introduced by an MNC. However, the document omitted any reference to freedom of association and the right to collective bargaining. ${ }^{17}$ Since the early

10 See: Schömann, I., op. cit., passim.

11 Marassi, M., Globalization and transnational collective labour relations. International and European framework agreements at company level, in: Blanpain, $\mathrm{R}$. (ed.), Bulletin for comparative labour relations, Alphen aan den Rijn 2015, p. 21.

12 Kaufmann, C., Globalisation and labour rights. The conflict between core labour rights and international economic law, Oxford-Portland 2007, p. 156.

13 Ibidem, p. 156.

14 Jenkins, R. et al., Introduction, in: Jenkins, R. et al., (eds.), Corporate responsibility and labour rights: codes of conduct in the global economy, London-Sterling, Vancouver 2002, p. 3.

15 Ibidem, p. 156.

16 Stohl C., et al., A new generation of corporate codes of ethics, "Journal of Business Ethics" 2009, No. 90, p. 614, DOI 10.1007/s10551-009-0064-6 (accessed 23.11.2019).

17 Egels-Zandén, N. and Merk, J., Private regulation and trade union rights: why codes of conduct have limited impact on trade union rights, "Journal of Business Ethics" 2014, No. 123, p. 463, DOI: 10.1007/s10551-013-1840-x (accessed 23.11.2019). 
1990s, a considerable number of MNCs have adopted codes, most of which fully or partly address employment standards. ${ }^{18}$

In 1999, the Global Sullivan Principles were launched in the presence of Kofi Annan, the UN Secretary General. On this occasion, he made a reference to the Global Sullivan Principles as important for the UN Global Compact (UN 2000). The Global Compact, named in literature as a "Model Code,"19 includes references to freedom of association and the right to collective bargaining, and "symbolises the evolution of the «international human rights regime» to incorporate what is described as the "third generation»". 20 In the area of labour, the Global Compact establishes the same principles as the ILO Declaration on Fundamental Principles and Rights at Work. However, the intended effect is to ensure that MNCs - rather than governments - comply with them. ${ }^{21}$ Interestingly, it does not address issues of monitoring. ${ }^{22}$

Corporate codes of conduct present both advantages and disadvantages. Some authors prove that they exert a positive impact on the workers' situation. For example, as Toffel, Short and Ouellet point out, private codes of conduct that implement global labour standards reinforce the norms promoted by the ILO and provide enforcement pressure that the ILO lacks. ${ }^{23}$ In addition, Harrington writes about the "quite positive results" of codes of conduct, especially in developing countries. ${ }^{24}$ Referring to corporate social responsibility policies, the author highlights that they can ensure that progressive labour standards are used even if they are not legally

18 Arthurs, H.W., Private ordering and workers' rights in the global economy: corporate codes of conduct as a regime of labour market regulation, in: Conaghan, J. et al., (eds.), Labour law in an era of globalization: transformative practices and possibilities, Oxford 2004, p. 474; see the cited literature. Bronstein, A., International and comparative labour law. Current challenges, Geneva 2009, p. 112.

20 "Third generation embodies the social and material conditions as well as the reflexivity associated with globalization, and ethical behavior grounded in the larger interconnected environment within which an organization functions", Stohl, C. et al., op. cit., p. 612; “Third generation CSR focuses on the rights of a collective that can only be realized through global participation, cooperation, and agreement. Sections mentioning overall social good, such as peace, healthy environment, and the common heritage of mankind, were coded as third generation", Ibidem, p. 614.

21 Lyutov, N., Traditional international labour law and the new "global" kind: is there a way to make them work together?, "Zbornik Pravnog Fakulteta u Zagrebu” 2017, No. 67, p. 33.

22 Bronstein, A., op. cit., p. 114.

23 Toffel, M.W. et al., Codes in context: how states, markets, and civil society shape adherence to global labor standards, "Regulation \& Governance" 2015, No. 9, p. 208. DOI: 10.1111/rego.12076 (accessed 23.11.2020).

24 Harrington, A.R., Corporate social responsibility, globalization, the multinational corporation, and labor: an unlikely alliance, "Albany Law Review" 2011/2012, No. 75, p. 493. See the cited literature. 
compulsory. She adds that in this manner, CSR can eventually lead to the future revision of domestic labour law..$^{25}$

However, there are also considerable concerns related to codes of conduct. The first-generation codes differ between companies and across industries, and there is little uniformity in their content. Many of them use vague language (especially as regards the freedom of association and wages), and for some rights, they are limited to asking for compliance with the supplier countries' domestic laws. Their underlying values are perceived as obscure. Codes of conduct mainly address marketing aims and respond to unfavourable publicity produced by the media. They are seen as a measure of propaganda and a means of improvement of an MNC's reputation, corporate legitimacy, trust, image or brand. One of their worst weaknesses is a lack of involvement of social partners in the decision-making process leading to the adoption of codes of conduct. Once adopted, they impose lower standards than public regulatory frameworks. Besides this, they are more selective in their choice of labour rights. ${ }^{26}$

In regard to the second generation, as supplier codes of conduct enjoyed rising popularity in the 1990s, advocates began to focus less on code adoption and more on compliance verification. ${ }^{27}$ The Sullivan Principles represent the first effort towards the implementation of codes of conduct with, e.g., monitoring schemes and independent monitoring in a multi-stakeholder forum. ${ }^{28}$ Currently, in relation to the third generation, there are always numerous problems with the implementation, monitoring and enforcement of a corporate code of conduct. ${ }^{29}$

\section{NGOs' social accountability standards}

Social accountability standards are created by non-governmental organisations (NGOs). In 1997, the NGO Social Accountability International established the Social Accountability Standard (SA8000) with the aim of implementing international

25 Ibidem, pp. 508-509.

26 Arthurs, H.W., op. cit., p. 477; Marassi S., op. cit., p. 22; Däubler, W., Corporate social responsibility: a way to make deregulation more acceptable?, in: Blanpain, R. and Hendrickx, F. (eds.), Bulletin for comparative labour relations. Labour law between change and tradition. Liber Amicorum Antoine Jacobs, Alphen aan den Rijn 2011, p. 49; Egels-Zandén, N. and Merk, J., op. cit., p. 464; Hepple, B., Labour laws and global trade, Oxford 2005, p. 76.

27 Herman, A., Reassessing the role of supplier codes of conduct: closing the gap between aspirations and reality, "Virginia Journal of International Law" 2012, No. 52, p. 455.

28 Segerlund, L., Making corporate social responsibility a global concern. Norm construction in a globalizing world, Farnham 2010, p. 56.

29 Hepple, B., op. cit., p. 76. 
labour standards and national labour laws. More specifically, the Standard mirrors labour provisions laid down in the ILO's conventions and the Universal Declaration of Human Rights. Moreover, it respects, supports and complements national labour laws all over the world. SA8000 is the leading social certification standard for factories and organisations around the globe. Social performance in areas crucial to social accountability in workplaces (child labour, forced or compulsory labour, health and safety, freedom of association and the right to collective bargaining, discrimination, disciplinary practices, working hours and remuneration) is measured through SA8000. It is anchored by a ninth element, i.e. a management system that drives continuous improvement in all of the above-mentioned areas. Given new and emergent social and human rights issues, regular revisions ensure the Standard's continuing applicability ${ }^{30}$. SA8000:2014 - which replaced SA8000:2008 - is the current version of the Standard. The most important updates to the Standard are related to forced or compulsory labour, as well as health and safety areas. All organisations certified to SA8000:2014 must now ensure that their workers are free from employment fees and costs, and they must establish a Health and Safety Committee responsible for monitoring health and safety hazards which is composed of management representatives and workers. ${ }^{31}$

As regards the SA8000 certification process, during the first phase, the applicant organisation undertakes an online management system self-assessment. Subsequently, it selects and works with one of the independent certification bodies (accredited by the Social Accountability Accreditation Services, SAAS) in order to start the full evaluation process. Once the organisation has implemented the necessary actions and improvements to become compliant with the Standard, the certification body grants the SA8000 certificate. Afterwards, the organisation is reviewed through on-site monitoring visits, both announced and unannounced. ${ }^{32}$

As explained by Bronstein, one of the characteristics of standards like the SA8000 is that certification pertains to factories and suppliers of the product and is not directed towards the retailers or the brand itself. Thus, by entering into business only with certified factories, MNCs encourage organisations to obtain certification. $^{33}$

30 http://www.sa-intl.org/index.cfm?fuseaction=Page.ViewPage\&PageID=1689 (accessed 23.11.2019).

31 http://www.sa-intl.org/index.cfm?fuseaction=Page.ViewPage\&pageId=1711 (accessed 23.11.2019).

32 http://www.sa-intl.org/index.cfm?fuseaction=Page.ViewPage\&pageId=1791 (accessed 23.11.2019).

33 Bronstein, A., op. cit., p. 122. 


\section{ISO standards}

Other private initiatives include the activities of the International Organization for Standardization (ISO). It is an independent, non-governmental international organisation that develops voluntary, consensus-based, market relevant International Standards which provide world-class specifications for products, services and systems to ensure quality, safety and efficiency. They are instrumental in facilitating international trade. ${ }^{34}$

In 2010, the International Organization for Standardization developed the ISO 26000 standard for corporate responsibility. It provides guidance on how businesses and organisations can operate in a socially responsible way, i.e. act in an ethical and transparent manner that contributes to the health and welfare of society. It is noteworthy that ISO 26000 provides only guidance and not requirements, thus it cannot be certified to unlike some other ISO standards. However, it plays an important role in clarifying what social responsibility is. Besides this, it helps businesses and organisations translate principles into effective actions and shares best practices relating to social responsibility globally. Crucially, it is addressed to all types of organisations, irrespective of their activity, size or location. ISO 26000 represents an international consensus, since representatives from labour organisations, NGOs, industry, government and consumer groups from around the world were involved in negotiations for five years and contributed to its development. ${ }^{35}$

In the above context, significant attention should be given to the interrelationship between the UN Sustainable Development Goals (SDGs) and ISO 26000. In other words, how can the ISO 26000 contribute to SDGs? When we think about this question, what first comes to mind is SDG 8: Promote sustained, inclusive and sustainable economic growth, full and productive employment and decent work for all. The case of the Algerian drinks producer NCA Rouiba is a good example of ISO 26000 in action. When it started the implementation of ISO 26000, staff welfare was given high priority. A new employee relations framework was developed with the aim of preventing discrimination and promoting well-being. It was established in association with trade unions and worker representatives. NCA Rouiba updated contracts with suppliers and insisted they implement the same standards. Another example that can be found on the ISO website relates to SDG 1: No poverty. For this one goal, Subclause 6.4.4.2 of ISO 26000 under the core subject "Labour practices" states: "An organisation should pay wages at least adequate for the needs of workers and their families. In doing so, it should take into account the general level of

34 https://www.iso.org/about-us.html (accessed 23.11.2019).

35 https://www.iso.org/iso-26000-social-responsibility.html (accessed 23.11.2019). 
wages in the country, the cost of living, social security benefits and the relative living standards of other social groups."36

ISO has also developed a standard that will help organisations to improve employee safety, reduce workplace risks and create better, safer working conditions all over the world. Here we talk about ISO 45001 Occupational health and safety. ${ }^{37}$ Unlike ISO 26000, it was created to be certifiable and to verify the safety and soundness of worker safety procedures. As highlighted by Cooper, organisations have two options: they can accept certification to this standard or adopt it as self-certification in the form of internal practice. Regardless of the choice made, ISO 45001 is aimed at creating a necessary foundation of worker safety and building integrity standards and conformance that can be accepted all over the world. ISO 45001 furnishes all industries, workers, other stakeholders and governmental agencies with operative and useful guidance for improving worker safety. ${ }^{38}$

This all sounds good in theory, but in practice, a dispute arose between the ILO and the ISO, mainly over the ISO 45001 standard on occupational safety and health management systems. The ILO wanted to reserve its exclusive right to create standards protecting workers' safety. It emphasised that its legitimacy results from being a treaty-based organisation, working directly with nation-states. ${ }^{39}$ Admittedly, the Agreement between the ILO and the International Organization for Standardization was signed on 6 August 2013, but the ILO formally notified the International Organization for Standardization on 18 December 2017 of its decision to terminate it (going into effect on 8 March 2018). The decision followed a review by the ILO Governing Body of a report on the ILO's pilot implementation of that Agreement (which was in the context of development of an ISO occupational health and safety management systems standard, namely ISO 45001). It was found that the implementation of the said document over four years did not reach the objectives of the Agreement. The conflict between the ISO standards and international labour standards was crucial here. According to paragraph 4 of the Agreement, "Given the broad mandate and action of the ILO to promote social justice and decent work, and ISO's broad mission, ISO standards that relate to issues within the ILO's mandate (ILO issues) should respect and support the provisions of ILS and related ILO action, including by using ILS as the source of reference with respect to ILO issues in case

36 ISO 26000 and the SDGs, https://www.iso.org/files/live/sites/isoorg/files/store/en/PUB100401.pdf (accessed 23.11.2019). https://www.iso.org/iso-45001-occupational-health-and-safety.html (accessed 23.11. 2019).

Cooper, S., Global supply chain governance: ILO, ISO \& Worker Safety, "Professional Safety" 2018, pp. 71-72. 
of conflict." Organisations could not reach a consensus on the question whether development of ISO standards required treating international labour standards "as the source of reference" or whether the ISO only needed to consider but not to refer to international labour standards. As highlighted by the ILO, the private standards involve the risk of leaving workers without protection in a situation where an international labour standard (concluded through tripartite consensus and given effect for decades) does not constitute the basis for private standards on issues related to the work of the ILO. As stated on the ILO website, according to the decision of the Governing Body, the ILO has no intention to seek to renew collaboration with the ISO without adequate safeguards ensuring respect of ILO standards. ${ }^{40}$

\section{The Dow Jones Sustainability Index (DJSI)}

The Dow Jones Sustainability Index (DJSI) was launched in 1999 and is considered a significant standard for corporate sustainability. It provides an instrument to track the financial performance of leading companies around the world and to measure their progress in sustainability. Created jointly by S\&P Dow Jones Indices and RobecoSAM (Sustainable Asset Management), the DJSI selects the most sustainable companies from across 61 industries. ${ }^{41}$ From the point of view of MNEs, being listed on the DJSI translates into getting access to significant investment capital. Additionally, taking into account the DJSI's global renown, companies always try to leverage their position on the DJSI in enhancing their own reputation. ${ }^{42}$

As regards reporting under DJSI, it includes three categories that cover the "triple bottom line"43: economic, environmental and social. The latter embraces an important aspect for our research, namely human rights, which contains investment, non-discrimination, freedom of association and collective bargaining, child labour, forced or compulsory labour, security practices, indigenous rights, assessment, supplier human rights assessment and human rights grievance mechanisms. Another reporting aspect is associated with labour practices and decent work. It encompasses: employment, labour-management relations, occupational health and safety, training and education, diversity and equal opportunity, equal remuneration

40 https://www.ilo.org/global/about-the-ilo/newsroom/statements-and-speeches/WCMS_617802/ lang--en/index.htm (accessed 23.11.2019).

41 https://www.robecosam.com/csa/indices/djsi-index-family.html (accessed 23.11.2019).

42 D'heur, M., Shared.Value.Chain: profitable growth through sustainable value creation, in: D'heur, M. (ed.), Sustainable value chain management: delivering sustainability through the core business, Cham 2015, p. 57.

43 Fiksel, J., Design for environment: a guide to sustainable product development, New York 2009, p. 40. 
for women and men, supplier assessment for labour practices and labour practices grievance management. ${ }^{44}$

However, it is worth stressing that the DJSI keeps itself informed primarily through the SAM questionnaire, which is completed by the companies invited to take part in SAM's Corporate Sustainability Assessment. The second source of information is company and third-party documents, as well as personal contacts between analysts and companies. ${ }^{45}$

In light of these reflections, there is little doubt that a self-reporting method which is not based on observations of a real company's progress in sustainability is not the best. Beside this, the DJSI is favourable towards the world's largest companies and excludes smaller ones. As an example, in 2019, over 3,500 of "the world's largest companies" were invited to participate in SAM's Corporate Sustainability Assessment. $^{46}$

\section{The Global Reporting Initiative (GRI)}

The Global Reporting Initiative (GRI) is an independent international organisation based in Amsterdam that has pioneered sustainability reporting since 1997. According to its website, the GRI works with the largest companies in the world and contributes to social well-being, better jobs, less environmental damage, access to clean water, less child and forced labour and gender equality. ${ }^{47}$

The organisation prides itself on the fact that the GRI Sustainability Reporting Standards are the first and the most broadly adopted global standards for sustainability reporting. ${ }^{48}$ Developed by the Global Sustainability Standards Board, the GRI Standards give all organisations the possibility of reporting publicly on their economic (the 200 series of the GRI Standards), environmental (the 300 series of the GRI Standards) and social (the 400 series of the GRI Standards) impacts and contributions to sustainable development. ${ }^{49}$ For reporting on its material topics, an organisation selects from the set of topic-specific GRI Standards. Interestingly, the

44 Sikdar, S.K. et al., Measuring progress towards sustainability: a treatise for engineers, Cham 2017, p. 120.

Fiksel, J., op. cit., p. 41.

https://www.finchandbeak.com/1451/the-2019-global-dow-jones-sustainability.htm (accessed 23.11.2019). 
400 series of the GRI Standards can be described as thematically oriented standards used to report information on an organisation's material impacts exerted on social topics. All Standards included in the 400 series have been effective since 1 July 2018 (with the exception of GRI 403, which will be effective from 1 January 2021). The Standards are the following: GRI 401: Employment, GRI 402: Labor/Management Relations, GRI 403: Occupational Health and Safety, GRI 404: Training and Education, GRI 405: Diversity and Equal Opportunity, GRI 406: Non-discrimination, GRI 407: Freedom of Association and Collective Bargaining, GRI 408: Child Labor, GRI 409: Forced or Compulsory Labor, GRI 410: Security Practices, GRI 411: Rights of Indigenous Peoples, GRI 412: Human Rights Assessment, GRI 413: Local Communities, GRI 414: Supplier Social Assessment, GRI 415: Public Policy, GRI 416: Customer Health and Safety, GRI 417: Marketing and Labeling, GRI 418: Customer Privacy and GRI 419: Socioeconomic Compliance. ${ }^{50}$

One can approximate the operation of the Standards using the example comprising human rights. Thus, for the purposes of this research, the focus here is on GRI 406: Non-discrimination, which establishes reporting requirements on the issue of non-discrimination. It can be used by an organisation of any type, size, sector or geographic location that is keen on reporting on its impact in this field (a common feature of all standards). This Standard defines discrimination as "the act and the result of treating people unequally by imposing unequal burdens or denying benefits, instead of treating each person fairly on the basis of individual merit." Discrimination includes harassment, which is defined as "a course of comments or actions that are unwelcome, or should reasonably be known to be unwelcome, to the person towards whom they are addressed". Importantly, an organisation shall avoid discriminating against any person on any grounds, including discriminating against workers. In order to help understand and apply the Standard, it refers back to ILO Conventions Nos. 100 and 111, as well as other instruments of the OECD and the UN. Given this context, it should be highlighted that GRI 406: Non-discrimination includes disclosures on the management approach and topic-specific disclosures. "Disclosure 406-1: Incidents of discrimination and corrective actions taken" establishes reporting requirements. The key point is that in this case, a selfreporting method is also used. The organisation shall report the total number of incidents of discrimination during the reporting period, as well as the status of the incidents and actions taken with reference to: incidents reviewed by the organisation; remediation plans being implemented; remediation plans that have been

50 https://www.globalreporting.org/standards/gri-standards-download-center/ (accessed 23.11.2019). 
implemented, with results reviewed through routine internal management review processes; incidents no longer subject to action. ${ }^{51}$

\section{Conclusion}

CSR norms are developed beyond the power of the state, cannot be enforced through the court processes and are adopted voluntarily within the private sector, often with the aim of enhancing a company's reputation or getting access to significant investment capital. This may all be perceived as evidence of the limited impact of CSR instruments on labour rights. Within the rich spectrum of CSR instruments that has been discussed, TCAs seem to be attractive mainly because of the benefits of social dialogue and the involvement of trade unions and workers in their drafting, monitoring and implementing. However, as has been raised, their legal nature and impact remain necessary to clarify. Unilateral corporate codes of conduct also present some disadvantages, inter alia, related to their implementation, monitoring and enforcement. Moreover, the self-reporting method inscribed in the nature of CSR instruments (e.g. the DJSI) gives only the illusion of impeccable operation by MNCs. Last but not least, it would be difficult not to mention the dispute that arose between the ILO and the ISO, mainly over the ISO 45001 standard, which is an example of a conflict between public and private organisations. In conclusion, CSR tools can be perceived only as additional value to law and - as such - can be further developed, mainly because they have a potential to encourage MNCs to raise standards (e.g. to obtain certification in the case of SA8000), to exert a positive impact on the workers' situation (e.g. codes of conduct) and to unite different stakeholders in carrying out one purpose, i.e. promoting labour rights.

\section{References}

Arthurs, H.W., Private ordering and workers' rights in the global economy: corporate codes of conduct as a regime of labour market regulation, in: Conaghan, J. et al. (eds.), Labour law in an era of globalization: transformative practices and possibilities, Oxford 2004.

Barreau, J. and Arnal, J., Effects of financialization on restructuring and sustainable development policy: the ACCOR Group Case, in: Sun, W. et al., (eds.), Finance and sustainability: towards a new paradigm? A post-crisis agenda, Bingley 2011.

51 https://www.globalreporting.org/standards/media/1021/gri-406-non-discrimination-2016.pdf (accessed 23.11.2019). 
Barrier, D., National policy regimes: implications for the activism-policy nexus, in: Utting, P. et al., (eds.), Global justice activism and policy reform in Europe: understanding when change happens, New York-London 2012.

Bronstein, A., International and comparative labour law. Current challenges, Geneva 2009.

Cooper, S., Global supply chain governance: ILO, ISO \& Worker Safety, "Professional Safety" 2018, October, pp. 70-74.

Cotton, E., Employment relations, international framework agreements and global unions, in: Roper, I. et al., (eds.), Critical issues in human resource management: contemporary perspectives, London 2020.

Däubler, W., Corporate social responsibility: a way to make deregulation more acceptable?, in: Blanpain, R. and Hendrickx, F., (eds.), Bulletin for comparative labour relations. Labour law between change and tradition. Liber Amicorum Antoine Jacobs, Alphen aan den Rijn 2011.

D'heur, M., Shared.Value.Chain: profitable growth through sustainable value creation, in: D'heur, M. (ed.), Sustainable value chain management: delivering sustainability through the core business, Cham 2015.

Egels-Zandén, N. and Merk J., Private regulation and trade union rights: why codes of conduct have limited impact on trade union rights, "Journal of Business Ethics" 2014, No. 123, DOI: 10.1007/s10551-013-1840-x.

Fiksel, J., Design for environment: a guide to sustainable product development, New York 2009.

Harrington, A.R., Corporate social responsibility, globalization, the multinational corporation, and labor: an unlikely alliance, "Albany Law Review" 2011/2012, No. 75.

Hepple, B., Labour laws and global trade, Oxford 2005.

Herman, A., Reassessing the role of supplier codes of conduct: closing the gap between aspirations and reality, "Virginia Journal of International Law" 2012, No. 52.

Jenkins, R. et al., Introduction, in: Jenkins, R. et al., (eds.), Corporate responsibility and labour rights: codes of conduct in the global economy, London-Sterling, Vancouver 2002.

Kaufmann, C., Globalisation and labour rights. The conflict between core labour rights and international economic law, Oxford-Portland, Oregon 2007.

Lund-Thomsen, P. and Lindgreen, A., Corporate social responsibility in global value chains: where are we now and where are we going?, "Journal of Business Ethics" 2014, No. 123. DOI: 10.1007/s10551-013-1796-x.

Lyutov, N., Traditional international labour law and the new "global" kind: is there a way to make them work together?, "Zbornik Pravnog Fakulteta u Zagrebu" 2017, No. 67.

Marassi, S., Globalization and transnational collective labour relations. International and European framework agreements at company level, in: Blanpain R. (ed.), Bulletin for comparative labour relations, Alphen aan den Rijn 2015.

Ojeda-Avilés, A., Transnational labour law, Alphen aan den Rijn 2015. 
Schömann, I., Transnational company agreements: towards an internationalisation of industrial relations, in: Schömann, I. et al. (eds.), Transnational collective bargaining at company level. A new component of European industrial relations?, Brussels 2012, https://www.etui.org/Publications2/Books/Transnational-collective-bargaining-at-c ompany-level.-A-new-component-of-European-industrial-relations.

Segerlund, L., Making corporate social responsibility a global concern. Norm construction in a globalizing world, Farnham 2010.

Sikdar, S.K. et al., Measuring progress towards sustainability: a treatise for engineers, Cham 2017.

Stohl, C. et al., A new generation of corporate codes of ethics, "Journal of Business Ethics" 2009, No. 90, DOI 10.1007/s10551-009-0064-6.

Toffel, M.W. et al., Codes in context: how states, markets, and civil society shape adherence to global labor standards, "Regulation \& Governance" 2015, No. 9. DOI: 10.1111/ rego.12076.

\section{CITATION}

TYC, A., Corporate social responsibility instruments and their impact on labour rights, "Acta Iuris Stetinensis" 2020, No. 1 (Vol. 29), 177-191, DOI: 10.18276/ais.2020.29-12. 